\title{
Post mortem analysis of burned magnesia-chromite brick used in short rotary furnace of secondary lead smelting
}

\section{(Análise post mortem de um refratário de magnésia-cromita usado em um forno rotativo de redução de chumbo secundário)}

\author{
E.Prestes ${ }^{1}$, A.S.A.Chinelatto ${ }^{1}$, W. S. Resende ${ }^{2}$ \\ ${ }^{1}$ Departamento de Engenharia de Materiais, Universidade Estadual de Ponta Grossa \\ Av. Carlos Cavalcanti, 4748, Uvaranas, Ponta Grossa, PR 84030-900 \\ ${ }^{2}$ Indústrias Brasileiras de Artigos Refratários - IBAR, Av. Ibar 2, Poá, SP 08559-470 \\ epres@uol.com.br
}

\begin{abstract}
Burned magnesia-chromite bricks are the standard product for the lining of furnaces in lead industry, where the short service life is a great problem. Used sintered magnesia-chromite brick sample from short rotary furnace lining, sent by a secondary lead manufacturer, showed parallel cracks to the hot face due to structural spalling damage. The refractory infiltrated region and slag interface were analyzed using a scanning electron microscope with an energy dispersive spectroscopy analyzer, and X-ray diffraction powder analysis. Crucible corrosion test was performed to evaluate the influence of slag attack. The results showed that the structural spalling was due to strong $\mathrm{Pb}$-infiltration of the refractory microstructure by bath components of the furnace (metallic lead and lead sulphite) during the reduction process and that the slag infiltration had little contribution due to the good resistance of the magnesia-chromite bricks to FeO rich slag attack.
\end{abstract}

Keywords: short rotary furnace of secondary lead smelting, post mortem analysis, used sintered magnesia-chromite brick.

\section{Resumo}

Os tijolos refratários queimados de magnésia-cromita são os produtos padrões para emprego no revestimento de fornos na indústria de chumbo, onde o curto tempo de vida desses refratários é um grande problema. Amostras de tijolos de magnésiacromita sinterizados, utilizados em um forno rotativo de redução de chumbo secundário, mostraram fissuras paralelas à face quente indicando que o desgaste do revestimento ocorreu por termoclase estrutural. As regiões de interface refratário-escória e de infiltração foram analisadas por microscopia eletrônica de varredura e espectroscopia de energia dispersiva, e difração de raios $X$. O teste de corrosão pelo método estático foi feito para avaliar a influência do ataque por escória. Os resultados mostraram que a termoclase estrutural foi devido a forte infiltração do chumbo, proveniente dos componentes do forno (chumbo metálico e sulfeto de chumbo), na microestrutura do refratário durante o processo de redução, e que, a infiltração da escória teve pouca contribuição devido a boa resistência dos refratários de magnésia-cromita a escórias ricas em $\mathrm{FeO}$.

Palavras-chave: forno rotativo de redução de chumbo secundário, análise "post mortem", refratários de magnésia-cromita sinterizados.

\section{INTRODUCTION}

The recycled lead obtained mainly from the recovery of lead from lead-acid batteries is named secondary lead [1]. The process of smelting and reduction is carried out in short rotary furnaces where the lead metallic scrap composed of $\mathrm{Pb}, \mathrm{PbO}_{2}$ and $\mathrm{PbSO}_{4}$ is added together with $\mathrm{C}$ and $\mathrm{Fe}$ as reductant agents and $\mathrm{Na}_{2} \mathrm{CO}_{3}$ as flux [2]. The oxi-reduction reactions occur at temperatures above $1000{ }^{\circ} \mathrm{C}$ and the slag produced in the process presents high content of $\mathrm{FeO}$ component. A typical slag composition is given in Table I.

Burned magnesia-chromite bricks are the standard product for the lining of short rotary furnaces since $\mathrm{MgO}$ shows good resistance to solvent action of $\mathrm{FeO}$ and the $\mathrm{Cr}_{2} \mathrm{O}_{3}$ improves the hot mechanical resistance [3, 4]. Figs .1a and $1 \mathrm{~b}$ show the $\mathrm{MgO}-\mathrm{FeO}$ and $\mathrm{MgO}-\mathrm{Fe}_{2} \mathrm{O}_{3}$ phase diagrams.
The good resistance of $\mathrm{MgO}$ to solvent action of $\mathrm{FeO}$ is due to solid reaction products: magnesio-wustite (MgO$\mathrm{FeO})$ or magnesio-ferrite $\left(\mathrm{MgO} \cdot \mathrm{Fe}_{2} \mathrm{O}_{3}\right)$, which occurs at the refractory/liquid iron oxides interface separating magnesia from the slag. At a temperature of $1600{ }^{\circ} \mathrm{C}, \mathrm{MgO}$ can dissolve up to $70 \mathrm{wt} \% \mathrm{FeO}$ without liquid formation and, even after $\mathrm{MgO}$ absorbs $\sim 100 \mathrm{wt} \% \mathrm{Fe}_{2} \mathrm{O}_{3}$, no liquid forms. At $1700{ }^{\circ} \mathrm{C}, \mathrm{MgO}$ can take up $\sim 65 \mathrm{wt} \% \mathrm{FeO}$ and $70 \mathrm{wt} \%$ $\mathrm{Fe}_{2} \mathrm{O}_{3}$ without developing a liquid phase. For the analysis of the $\mathrm{Cr}_{2} \mathrm{O}_{3}$ influence in magnesia products, $\mathrm{MgO}-\mathrm{FeO}-\mathrm{Fe}_{2} \mathrm{O}_{3}$ and pseudo-ternary $\mathrm{MgO}-\mathrm{FeO}-\mathrm{Fe}_{2} \mathrm{O}_{3}-\mathrm{Cr}_{2} \mathrm{O}_{3}$ diagrams (Figs. $2 \mathrm{a}$ and $2 \mathrm{~b}$ ) show the influence of an addition of chromium oxide on the corrosion of magnesia refractories in the presence of iron oxide [5].

With higher $\mathrm{Cr}_{2} \mathrm{O}_{3}$ content, the corrosion is lower. An extension of the spinel $\mathrm{Mg}(\mathrm{Cr}, \mathrm{Fe})_{2} \mathrm{O}_{4}$ region and a reduction 
Table I - Typical slag composition of a secondary lead production [3].

[Tabela I - Composição típica de uma escória de produção de chumbo secundário [3].]

\begin{tabular}{cccccccccc}
\hline Component & $\mathrm{FeO}$ & $\mathrm{SiO}_{2}$ & $\mathrm{CaO}$ & $\mathrm{Na}_{2} \mathrm{O}$ & $\mathrm{PbO}$ & $\mathrm{As}$ & $\mathrm{SO}_{3}$ & $\mathrm{ZnO}$ & Others \\
\hline Content [\%] & 32.0 & 18.0 & 2.20 & 20.0 & 3.0 & 0.2 & 10.0 & 4.0 & 10.6 \\
\hline
\end{tabular}
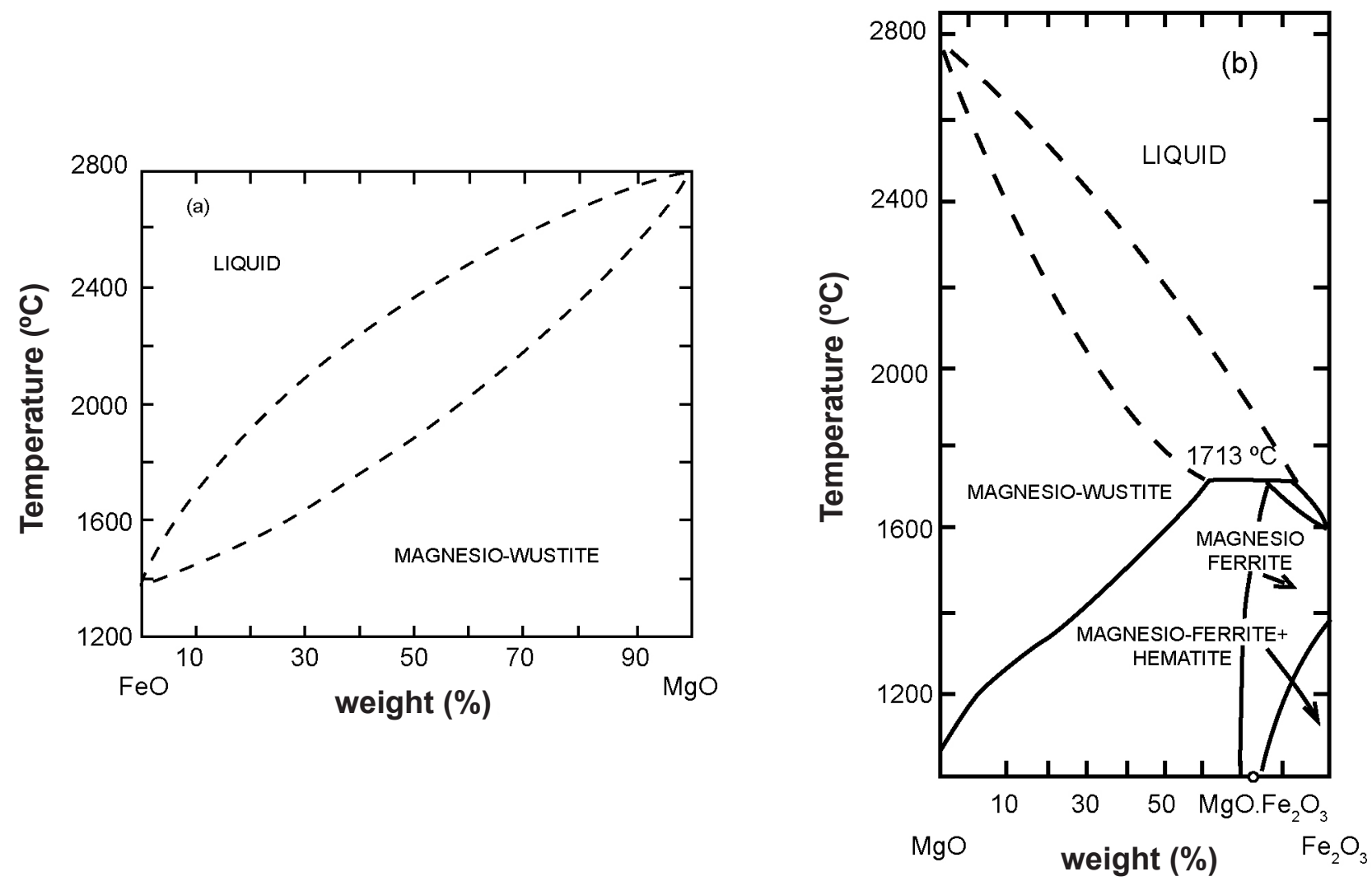

Figure 1: Phase diagrams of the $\mathrm{FeO}-\mathrm{MgO}$ (a) and $\mathrm{MgO}-\mathrm{Fe}_{2} \mathrm{O}_{3}$ (b) systems [4].

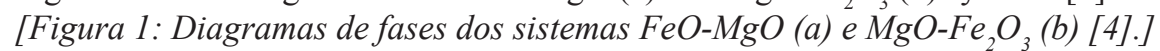
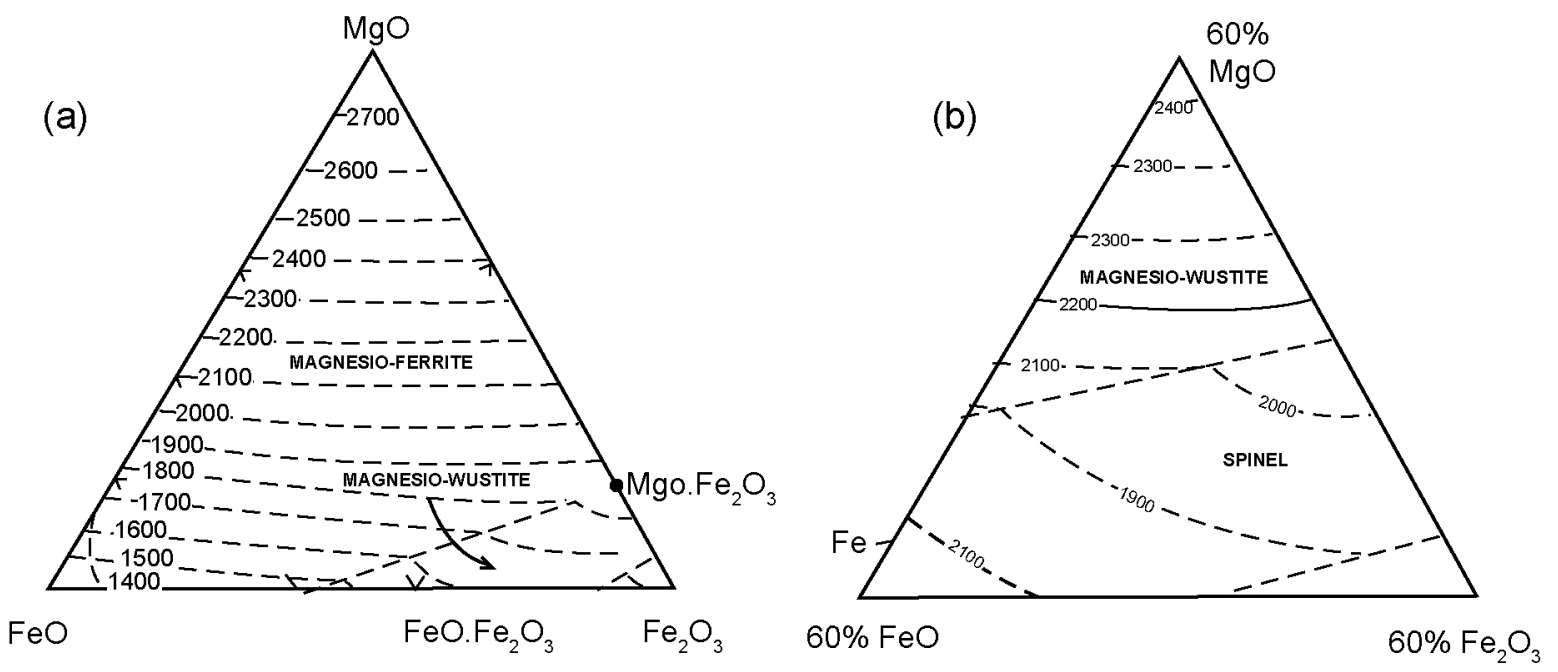

Figure 2: Liquidus surfaces in the $\mathrm{MgO}-\mathrm{FeO}-\mathrm{Fe}_{2} \mathrm{O}_{3}$ (a) and pseudo-ternary $\mathrm{MgO}-\mathrm{FeO}-\mathrm{Fe}_{2} \mathrm{O}_{3}-40 \% \mathrm{Cr}_{2} \mathrm{O}_{3}$ systems (b) [4]. [Figura 2: Superficie liquidus nos sistemas $\mathrm{MgO}-\mathrm{FeO}-\mathrm{Fe}_{2} \mathrm{O}_{3}$ (a) e do pseudo-ternário $\mathrm{MgO}-\mathrm{FeO}-\mathrm{Fe}_{2} \mathrm{O}_{3}-40 \mathrm{p}_{2} \mathrm{Cr}_{2} \mathrm{O}_{3}$ (b) [4].] 
Table II - Typical magnesia-chromite bricks properties [3].

[Tabela II - Propriedades típicas de refratários formados de magnésia-cromita [3].]

\begin{tabular}{cccccccccc}
\hline Main components & $\begin{array}{c}\mathrm{MgO} \\
\%\end{array}$ & $\begin{array}{c}\mathrm{Cr}_{2} \mathrm{O}_{3} \\
\%\end{array}$ & $\begin{array}{c}\mathrm{Fe}_{2} \mathrm{O}_{3} \\
\%\end{array}$ & $\begin{array}{c}\mathrm{Al}_{2} \mathrm{O}_{3} \\
\%\end{array}$ & $\begin{array}{c}\mathrm{CaO} \\
\%\end{array}$ & $\begin{array}{c}\mathrm{SiO}_{2} \\
\%\end{array}$ & $\begin{array}{c}\mathrm{BD} \\
\mathrm{g} / \mathrm{cm}^{3}\end{array}$ & $\begin{array}{c}\mathrm{CCS} \\
\mathrm{N} / \mathrm{mm} 2\end{array}$ & $\begin{array}{c}\mathrm{AP} \\
\%\end{array}$ \\
\hline $\begin{array}{c}\text { Sinter mag. } \\
(\mathrm{MgCO})+\text { chrome } \\
\text { ore / direct bond }\end{array}$ & 58.0 & 19.0 & 15.0 & 6.0 & 1.3 & 0.6 & 3.28 & $>30$ & $<18$ \\
$\begin{array}{c}\text { Sinter mag. (synth.) } \\
\text { + chrome ore / } \\
\text { direct bond }\end{array}$ & 58.0 & 21.0 & 13.0 & 6.5 & 0.6 & 0.3 & 3.27 & $>30$ & $<18$ \\
$\quad \begin{array}{c}\text { Co-clinker } \\
\text { (Oxicrom) }\end{array}$ & 60.0 & 18.0 & 14.0 & 6.0 & 1.3 & 0.6 & 3.26 & $>40$ & $<17$ \\
$\begin{array}{c}\text { Fused magnesia }+ \\
\text { chrome ore }\end{array}$ & 57.0 & 21.0 & 13.0 & 6.5 & 1.2 & 0.7 & 3.28 & $>30$ & $<18$ \\
$\begin{array}{c}\text { Fused magnesia } \\
\text { chromite }\end{array}$ & 56.0 & 21.0 & 14.5 & 6.5 & 1.3 & 0.7 & 3.30 & $>30$ & $<18$ \\
$\quad \begin{array}{c}\text { Co-clinker } \\
\text { (Oxicrom) } \\
\text { micro powder }\end{array}$ & 57.0 & 20.0 & 15.0 & 6.5 & 1.3 & 0.6 & 3.37 & $>70$ & $<13$ \\
\hline
\end{tabular}

of the solid solution $\mathrm{MgO}-\mathrm{FeO}$ area can be noticed. With high oxidizing conditions, the liquidus temperatures strongly rise for high values of iron oxide [4]. Table II shows chemical and physical properties of different magnesia-chromite bricks for the lining of furnaces in the lead industry.

The base materials for the production of these bricks are sintered magnesia and natural mined cromite respectively by fusing producing magnesia-chromite or by sintering produced co-clinker (Oxicrom). Silicate bonded bricks are not suitable for the application in lead furnaces due to their low hot properties and low resistance against acid slags [6]. Direct bonded bricks present good thermal shock resistance because of their heterogeneous structure and also good slag resistance. Improved slag resistance because of formation of primary and secondary chromite spinels at the periclase surface, but lower thermal shock resistance is reached with bricks made from co-clinker bricks. Fused magnesiachromite bricks show higher corrosion resistance compared to co-clinker bricks, especially due to their larger crystal sizes $[6,7]$.

It is possible to improve the brick properties further by adding e.g. pure chrome oxide powder which results in a higher slag resistance or micro powder, which, by filling the pores, will result into less infiltration, but lower thermal shock resistance [3].

Although burned magnesia-chromite bricks present good slag attack resistance to $\mathrm{FeO}$ rich slags, the short service life of burned magnesia-chromite bricks when employed in the lining of short rotary furnaces of secondary lead smelting is a great problem. Therefore, this paper relates the post mortem analysis of burned magnesia-chromite brick after use in a short rotary furnace of secondary lead smelting.

\section{MATERIALS AND METHODS}

After use, used sintered magnesia-chromite brick sample from short rotary furnace lining was supplied by a secondary lead manufacturer. Table III shows the brick properties.

The sample was cross-sectioned using a diamond saw and its cross-sectioned profile was photographed. Refractory samples from infiltrated region and refractory-slag interface were analyzed using a XRD 6000 scanning electron microscope (SEM) (Shimadzu SS-550) equipped with an energy dispersive spectroscopy (EDS) analyzer (Shimadzu SEDX-550). Backscattered electron imaging was carried out using carboncoated no polished samples. Samples for X-ray diffraction (XRD) powder analysis were crushed and sieved $(<325 \mathrm{mesh})$ and the pattern recorded on an X-ray unit (Shimadzu).

An used sintered magnesia-chromite brick was evaluated in the cup test. The sample was placed with a fixed amount $(170 \mathrm{~g})$ of powdered slag and fired for $5 \mathrm{~h}$ at $1400^{\circ} \mathrm{C}$ and $1500{ }^{\circ} \mathrm{C}$ at a heating rate of $2{ }^{\circ} \mathrm{C} / \mathrm{min}$. Table IV shows the slag composition.

Table III - Brick properties.

[Tabela III - Propriedades dos tijolos.]

\begin{tabular}{ccccccc}
\hline \multicolumn{6}{c}{ Chemical composition-mass\% } \\
\hline $\mathrm{MgO}$ & $\mathrm{Cr}_{2} \mathrm{O}_{3}$ & $\mathrm{Fe}_{2} \mathrm{O}_{3}$ & $\mathrm{Al}_{2} \mathrm{O}_{3}$ & $\mathrm{SiO}_{2}$ & $\mathrm{CaO}$ & Others \\
61.5 & 19.0 & 12.0 & - & 1.0 & - & 6,5 \\
\hline \multicolumn{7}{c}{ Physical properties } \\
\hline Cold crushing & Bulk density & Apparent porosity \\
strength (MPa) & $\left(\mathrm{g} / \mathrm{cm}^{3}\right)$ & $(\%)$ \\
80.0 & 3.05 & 17.0 \\
\hline
\end{tabular}


Table IV- Slag composition.

[Tabela IV - Composição da escória.]

\begin{tabular}{ccccccccc}
\hline Component & $\mathrm{FeO}$ & $\mathrm{SO}_{3}$ & $\mathrm{Na}_{2} \mathrm{O}$ & $\mathrm{SiO}_{2}$ & $\mathrm{Al}_{2} \mathrm{O}_{3}$ & $\mathrm{CaO}$ & $\mathrm{PbO}$ & Others \\
\hline Content $-\%$ & 51.9 & 15.9 & 13.2 & 10.4 & 2.09 & 1.96 & 1.56 & 2.99 \\
\hline
\end{tabular}

After the corrosion testing, crucible samples were crosssectioned using a diamond saw and their cross-sectioned profiles were photographed. The slag penetration area in each sample was measured using the analysis image software "Image-Pro Plus 5.1".

\section{RESULTS AND DISCUSSION}

\section{Post mortem analysis}

Fig. 3 shows the visual appearance of used magnesiachromite brick after use in short rotary furnace of secondary lead smelting.

The used brick shows parallel cracks to the hot face, indicating damage due to structural spalling. This damage is due to microstructural changes in the refractory superficial layer, by porosity reduction or reaction with solids and liquids in contact. Properties of this superficial layer differ from unaltered refractory microstructure. Temperature fluctuations, by cycles of cooling and heating, can lead to detachment of this layer.

Fig. 4 a shows the cross-sectioned profile of the refractory sample. Figs. $4 \mathrm{~b}$ and $4 \mathrm{c}$ show the backscattered electron image of infiltrated region and the refractory-slag interface, respectively.

Fig. $4 \mathrm{~b}$ shows the presence of a bright phase in the microstructure of infiltrated region. The resulting densification (by infiltration of this phase) promoted the damage by structural spalling. Chemical composition analyzed with EDS for the infiltration and refractory-slag interface regions is given in Table $\mathrm{V}$.

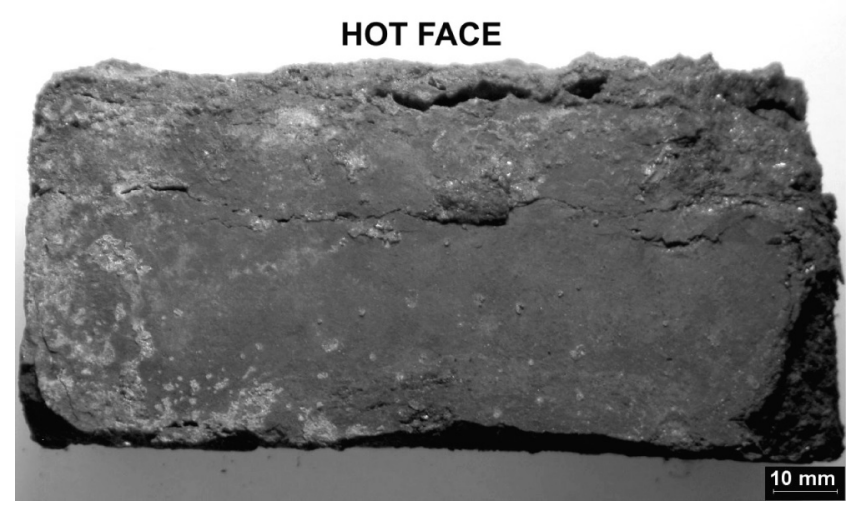

Figure 3: Visual appearance of used magnesia-chromite brick after use in short rotary furnace of secondary lead smelting.

[Figura 3: Aspecto visual do refratário formado de magnésiacromita "M2" após utilização em forno rotativo de redução de chumbo secundário.]
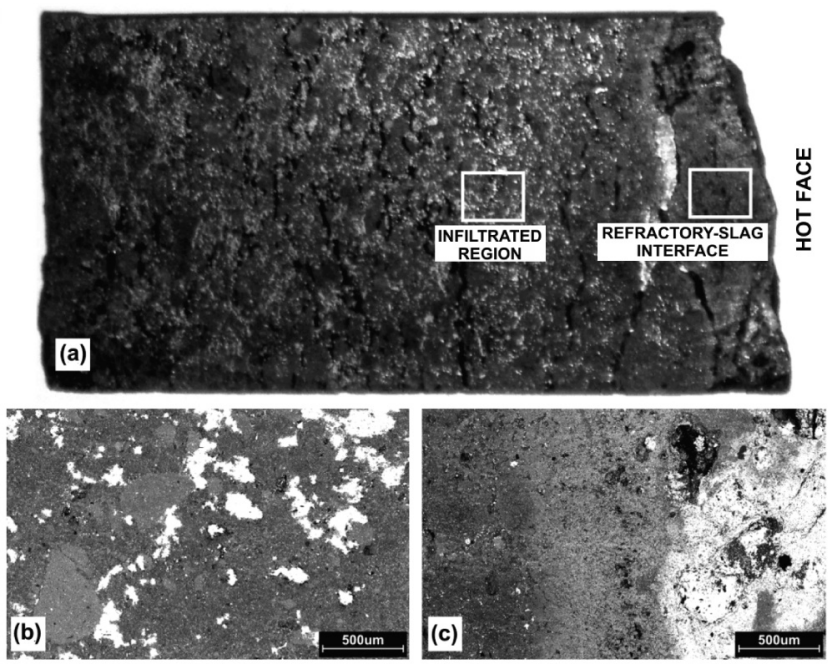

Figure 4: Cross-sectioned profile of the refractory sample (a) and backscattered electron image of infiltrated region (b) and the refractory-slag interface (c).

[Figura 4: Perfil seccionado da amostra de refratário (a) e região de infiltração utilizando elétrons retroespalhados e refratárioescória (b) e interface refratário-escória (c).]

Table V- Chemical composition - mass\%. [Tabela V - Composição química - \% massa.]

\begin{tabular}{ccc}
\hline Component & Infiltrated region & $\begin{array}{c}\text { Refractory-slag } \\
\text { interface }\end{array}$ \\
\hline $\mathrm{Na}_{2} \mathrm{O}$ & 5.28 & 5.86 \\
$\mathrm{MgO}$ & 23.84 & 18.91 \\
$\mathrm{Al}_{2} \mathrm{O}_{3}$ & 2.48 & 1.80 \\
$\mathrm{SiO}_{2}$ & 3.52 & 6.64 \\
$\mathrm{CaO}$ & 3.00 & 0.52 \\
$\mathrm{Cr}_{2} \mathrm{O}_{3}$ & 4.72 & 2.43 \\
$\mathrm{FeO}$ & 4.41 & 16.46 \\
$\mathrm{PbO}$ & 46.87 & 41.60 \\
$\mathrm{SO}_{3}$ & 5.90 & 5.78 \\
\hline
\end{tabular}

The high content of $\mathrm{PbO}$ in the infiltrated region shows that strong $\mathrm{Pb}$-infiltration of refractory microstructure occurred. The XRD pattern of the infiltrated region (Fig. 5) shows that the Pb-infiltrated (bright phase in the microstructure of infiltrated region) is present in the metallic lead and lead sulphide phases. These are components of the furnace bath during the reduction process of the battery scrap.

Figs. 6 and 7 show the EDS compositional maps for refractory-slag interface and infiltrated region, respectively. 


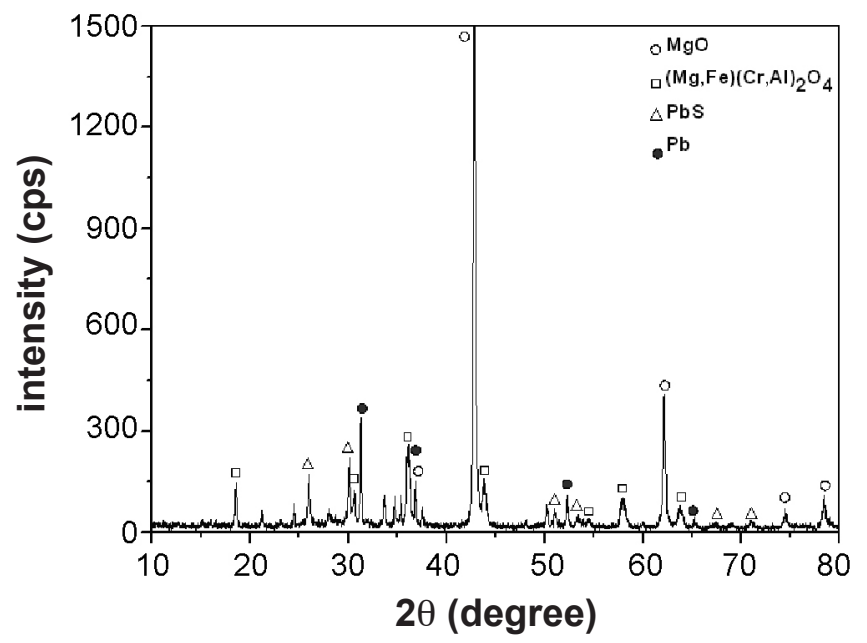

Figure 5: XRD pattern of infiltrated region.

[Figura 5: Difratograma de raios $X$ da região infiltrada.]
The EDS compositional maps of Fig. 6 indicate the low slag infiltration (Fe-element) at the refractory-slag interface, therefore the structural spalling is due to strong $\mathrm{Pb}$-infiltration, as shown in Fig. 7.

\section{Crucible corrosion test}

Fig. 8 shows the cross sections of used sintered magnesia-chromite brick after the cup test for $5 \mathrm{~h}$ at $1400{ }^{\circ} \mathrm{C}$ and $1500{ }^{\circ} \mathrm{C}$.

The low slag infiltration shows the good resistance to $\mathrm{FeO}$ rich slag attack of the used sintered magnesia-chromite brick, due to the good resistance to solvent action of $\mathrm{FeO}$ by $\mathrm{MgO}$ phase and the $\mathrm{MgCr}_{2} \mathrm{O}_{4}$ which improve hot mechanical resistance and chemical corrosion [3, 4]. Therefore the slag attack had little contribution on structural spalling, as observed in Fig. 6 in the post mortem analysis (low Feinfiltration at the refractory-slag interface).
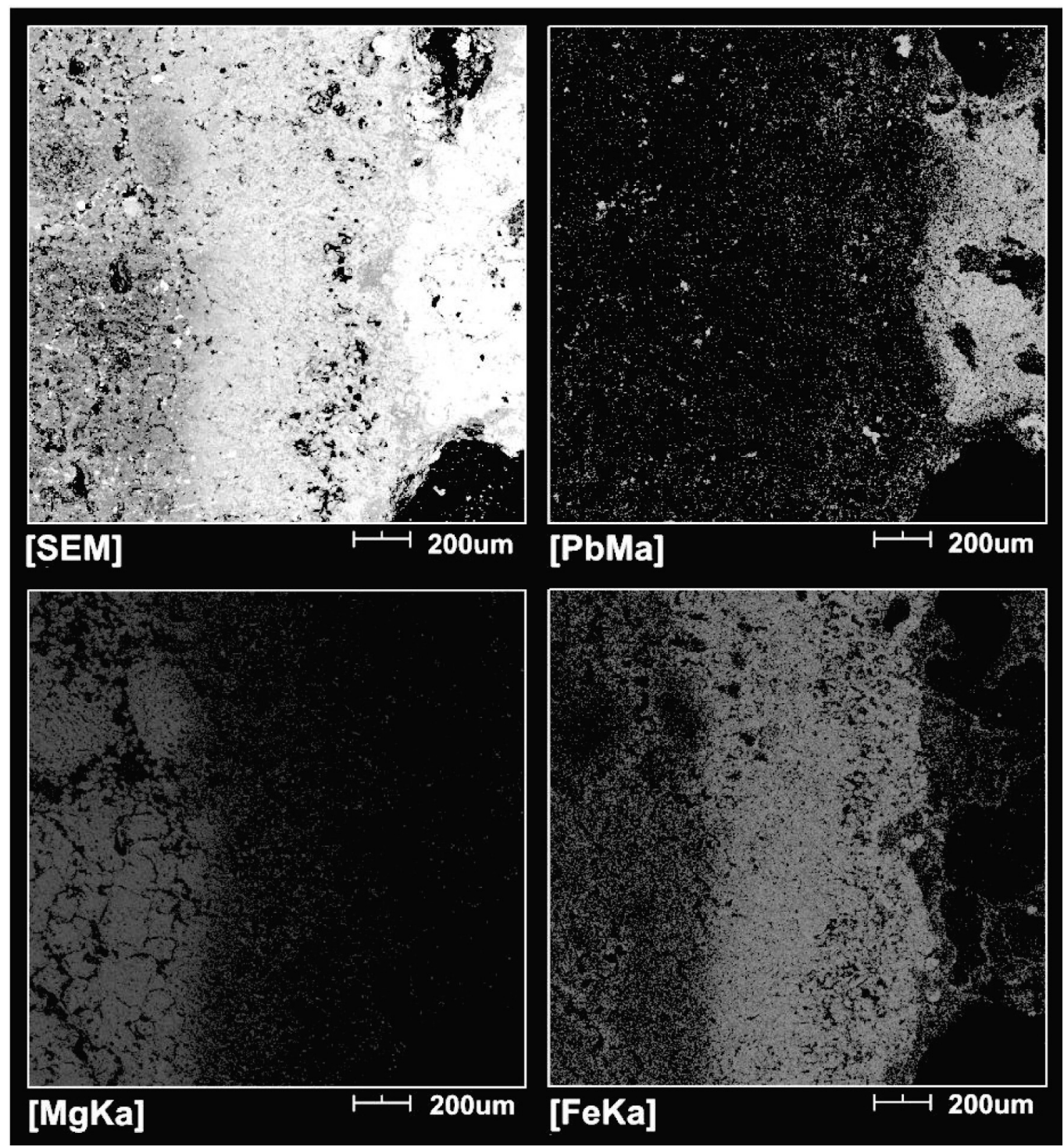

Figure 6: EDS compositional maps for $\mathrm{Pb}, \mathrm{Mg}$ and $\mathrm{Fe}$ of the refractory-slag interface.

[Figura 6: Mapeamento de raios X para os elementos $\mathrm{Pb}, \mathrm{Mg}$ e Fe da região de interface refratário-escória.] 


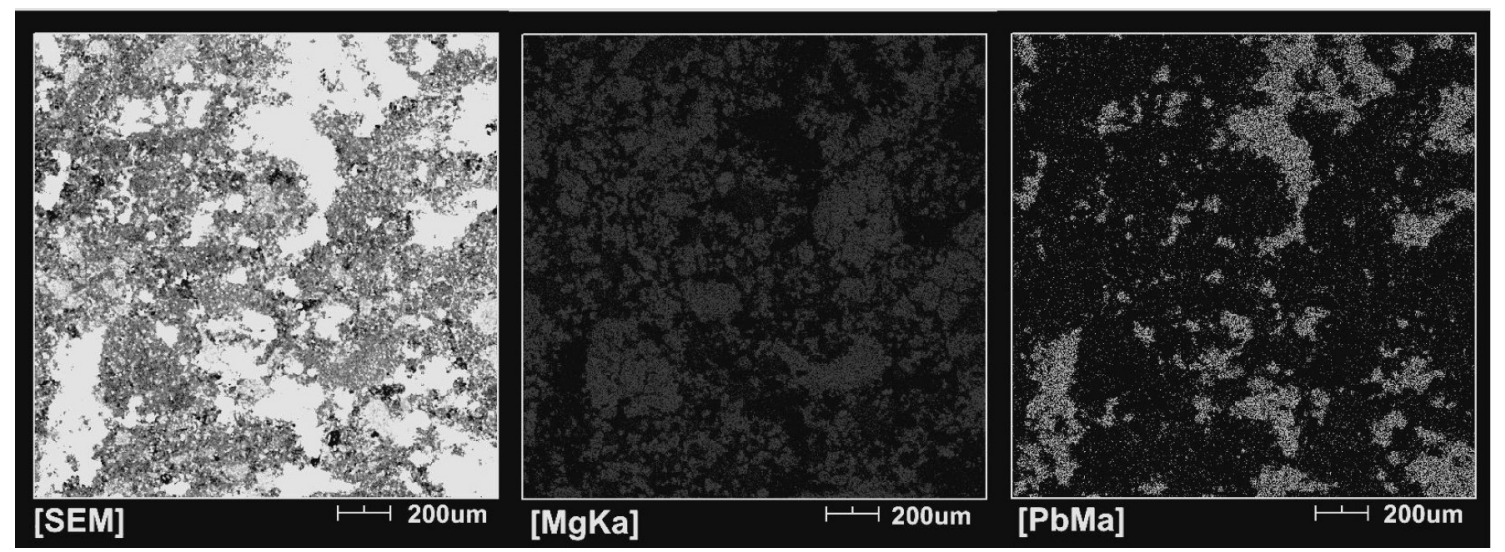

Figure 7: EDS compositional maps for $\mathrm{Pb}$ and $\mathrm{Mg}$ of the infiltrated region.

[Figura 7: Mapeamento de raios X para os elementos $\mathrm{Pb}, \mathrm{Mg}$ e Fe da região infiltrada.]

\section{Croos sections}
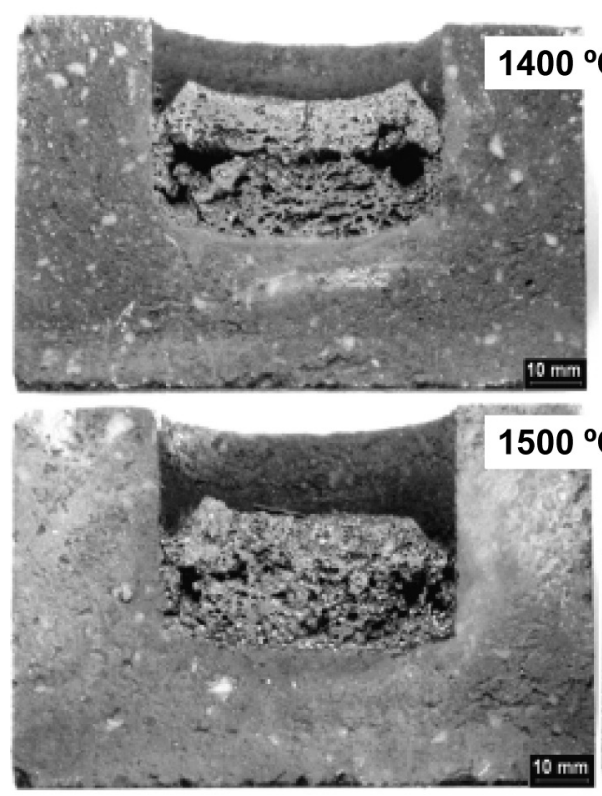
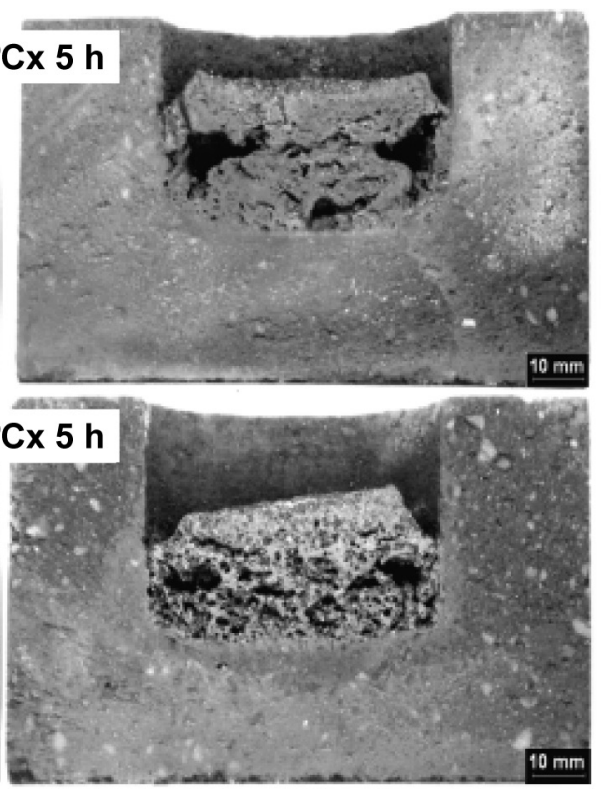

Mean Slag

penetration area

$1400^{\circ} \mathrm{C} \times 5 \mathrm{~h}$

$114.1 \mathrm{~mm}^{2}$

$1500{ }^{\circ} \mathrm{C} \times 5 \mathrm{~h}$

$247.0 \mathrm{~mm}^{2}$

Figure 8: Cross section of used sintered magnesia-chromite brick after the crucible corrosion test.

[Figura 8: Perfil seccionado do refratário de magnésia-cromita sinterizados após o teste de ataque por escória.]

\section{CONCLUSIONS}

The following conclusions can be reached about the post mortem analysis of burned magnesia-chromite used in short rotary furnace of secondary lead smelting:

- The short service life of the refractory lining is due to structural spalling by strong $\mathrm{Pb}$-infiltration;

- The slag attack had little contribution to the damage by structural spalling due to the good resistance of the burned magnesia-chromite bricks to $\mathrm{FeO}$ rich slag attack.

\section{REFERENCES}

[1] R. Jolly, C. Rhin Resources, Conservations and Recycling
10 (1994) 137.

[2] F. Chaves et al., Proc. Third Int. Symp. Recycling of Metals and Engineered Materials (1995) 337.

[3] T. Taschler, M. Köffel, Proc. Eur. Metallurgical Conf., Dresden, Germany (2005) 1045.

[4] J. Poirier, M. L. Bouchetou, Refractories Appl. Trans. 2, 3 (2006) 1.

[5] S. Zhang, W. E. Lee, Int. Mater. Ver. 45, 2 (2000) 41.

[6] A. M. Segadães, Refractarios, $1^{\text {st }}$ Ed., Fundação João Jacinto de Magalhães, Aveiro, Portugal (1997) 244.

[7] D. A. Brosnan Corrosion of Refractories, in M. Dekker Refractories Handbook, Clemson (2004) 39.

(Rec. 14/03/2008, Rev. 04/08/2008, Ac. 08/08/2008) 